\title{
$6(1)(2019) 6-10$
}

\section{Journal of Physical Education, Health and Sport}

http://journal.unnes.ac.id/nju/index.php/jpehs

\section{QR Code Based Teaching Materials for Organizational Classes and Game Systems}

\author{
Guntur Firmansyah $^{1 \bowtie}$, Didik Hariyanto ${ }^{2}$ \\ Physical Education, Health, and Recreation IKIP Budi Utomo Malang, East Java, Indonesia ${ }^{12}$
}

\section{History Article}

Received 19 April 2019 Approved 25 July 2019 Published 31 July 2019

\section{Keywords}

Teaching Materials; QR CODE; Organizational classes ang game systems

\begin{abstract}
To support the learning process of a course must be supported by teaching materials that are cheap, simple, easy to learn, easily accessible and quickly accessed by students. Along with the rapid advances in technology, many media have been developed both in print and online to support the learning process. One technology that is now widely known is the QR Code. This study aims to produce QR Code-based teaching materials that are easy to learn, easy and quickly accessible to improve learning motivation in organizational subjects and match systems. The research conducted is development research. The development model used is the $4 \mathrm{D}$ model developed by Thiagarajan, et al. 4D stages consisting of define, design, develop, and disseminate. In summary the data obtained from the evaluation of material experts showed $83 \%$, from the evaluation of linguists $83 \%$, evaluation of media experts $79 \%$ so it can be concluded that the product is feasible and good.
\end{abstract}

\section{How to Cite}

Firmansyah, G. \& Hariyanto, D. (2019). QR Code Based Teaching Materials for Organizational Classes and Game Systems. Journal of Physical Education, Health and Sport, 6 (1), 6-10.

(C) 2019 Universitas Negeri Semarang 


\section{INTRODUCTION}

In the current era of learning conducted at the tertiary level has undergone many changes and advances that lead to the use of a variety of advanced technology. The technology used to support the learning process is inseparable because indeed technology if used appropriately will have the effect of ease and success.

The use of technology such as students, for example, will immediately be able to feel the effects if the technology is appropriate for the needs of students. One of the needs of students is teaching material as a companion book in the learning process. Attractive teaching materials with sophisticated technology will surely be one of the solutions sought by students.

With the rapid development of technology, it should be used more directed at the learning process, one of the targets is teaching material. In recent years there have been a lot of teaching materials that have been developed by several researchers in accordance with the courses they teach such as teaching materials for local content-based citizenship education (Sulkipani, 2016), teaching materials for problem-based economic mathematics courses (Vahlia, 2016), algebra based teaching materials based on open ended (Suryadinata, 2016), teaching materials for sociology learning in HOTS oriented sociology (Poerwanti Hadi Pratiwi, Nur Hidayah, 2017).

Organizational courses and competition system is one of the subjects that students must take and master well. Teaching materials that might be developed in these courses are QR Code based teaching materials that offer convenience, speed in accessing both offline and online

Based on the initial needs analysis, it was obtained that students used cellular phones with very good specifications of $70 \%$, good $20 \%$ good enough $10 \%$ to access the internet quickly. For the needs of use in searching college material on the internet the categories are very often $80 \%$, often 15 rating, $5 \%$ quite often. Whereas for the use of teaching materials based on QR code students answer $100 \%$ and have never used them at all.

Based on the explanation from the background above, the writer formulates that the writer wants to develop teaching materials based on QR Code that are cheap, simple, easy to learn, easily accessed and quickly accessed to improve motivation to learn organizational courses and the competition system and as a provision and additional knowledge during taking lecture process. Then the aim of this research is to produce A5-sized printed teaching materials that contain organizational lectures and match systems that are equipped with images from the
QR Code that can be accessed directly using the QR Code scanner on a cell phone either online or offline

\section{Development Research}

According to the opinion expressed by (Winarno, 2011)»Development or what is often referred to as development research is carried out with the intention of bridging the gap that spreads quite wide between research and educational practice.» Development research is research that seeks to develop certain products according to the needs of today's society.

(Sukmadinata, 2005) defines development research, namely «a process or steps to develop a new product or improve existing products, which can be accounted for». In research development does not always develop new products, it can be by perfecting existing products that can be accounted for.

\section{Teaching Materials}

According to the Ministry of National Education in writing (Saluky, 2016), teaching materials can be developed in various forms that are tailored to the needs and characteristics of the material to be presented (Saluky, 2016). According to Prastowo, quoted (Saluky, 2016) «based on the form of teaching materials can be divided into four types, namely printed materials, including handouts, materials, modules, student worksheets, brochures, leaflets, wallcharts, photos/drawings, models/mockups.

\section{QR Code}

QR codes can send messages very quickly, and they are also very reliable with low cost and high capacity for messages. The information in the QR code varies, for example, link switching, location information, time stamp, corresponding platform user ID, all of which cannot be identified in the QR code image (Guo, Cao, Wang, Fu, \& $\mathrm{Li}, 2016$ )

The QR code is a $2 \mathrm{D}$ bar code that was discovered by the Denso Wave company, a subsidiary of Toyota, in 1994. Because Denso Wave chose not to use its patent rights, the QR code was open to the public. This means that developers are free to create new varieties of $\mathrm{QR}$ codes and applications to interpret and process the code coleman in (Meydanoglu, 2013).

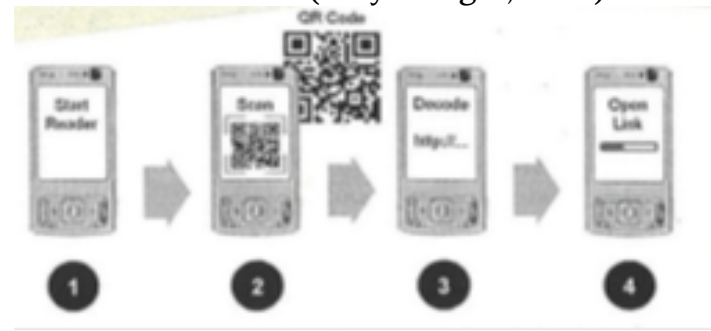

Figure 1. Way of Working QR Code (Meydanoglu, 2013) 


\section{Motivation}

Motivation to learn Understanding motivation in the opinion of Uno, states that the motivation contained in a person to try to make changes in behavior that is better in meeting their needs (Ani Asiani, Harini, 2017). Put forward things that make us continue to have motivation, namely: happy, satisfied, relieved, proud, involved, like, safe, ready, balanced, happy, respectable, trusted, and valued Rob dan Letts in (Monicca, Subkhan, \& Setiyani, 2015).

Internal and external encouragement to students who are learning to make changes in behavior, generally with a number of indicators or supporting elements. Indicators of learning motivation can be classified as follows: 1) There is a desire and desire to succeed, 2) There are encouragement and needs in learning, 3) There are hopes and ideals of the future, 4) There is an appreciation for learning 5) The existence of interesting activities in learning, 6) There is a conducive learning environment.

\section{METHOD}

The research conducted is development research. the development model used is the $4 \mathrm{~d}$ model developed by (Afandi, 2015) 4d stages consisting of define, design, develop, and disseminate. The study was conducted at Ikip Budi Utomo Malang. the research subject of the 2016 Ikip Budi Utomo Malang physical education and health physical education study program students who are currently taking courses and organization system. research time in odd semester 20182019.

\section{Research and development phase \\ Define}

Stage the analysis of instructional requirements needed includes the following steps: (1) analyzing the basic competencies of the organization's courses and competition systems, (2) identifying learning problems, and (3) identifying weaknesses and shortcomings of organizational teaching materials and existing competition systems.

\section{Design Stage}

This stage is carried out to produce an initial draft of the organization's teaching materials and a match system. This stage is carried out through the following steps: a) preparation of the benchmark reference test. Benchmark reference tests are used to assess the substance and structure of teaching materials to be developed, b) selection of the format of teaching materials is adjusted to the criteria of teaching material components that are adjusted to the needs analysis at the define stage.

\section{Develop Phase}

Revise the initial draft of instructional material that has been prepared at the design stage. Revisions are based on the validation process carried out by material experts, media experts (teaching material experts), and linguists. Each validator is an expert in his field.

\section{Disseminate Stage}

The use of teaching materials that have been developed on a broad scale and aims to test the effectiveness of the use of the results of development. Dissemination stage can be done in other classes with the aim of knowing the readability of teaching materials for students, students' responses to teaching materials, sheets of learning implementation, the effectiveness of teaching materials using devices in the learning process. This form of dissemination aims to obtain input, correction, suggestions, assessments, to improve the final product development to be ready for use by product users.

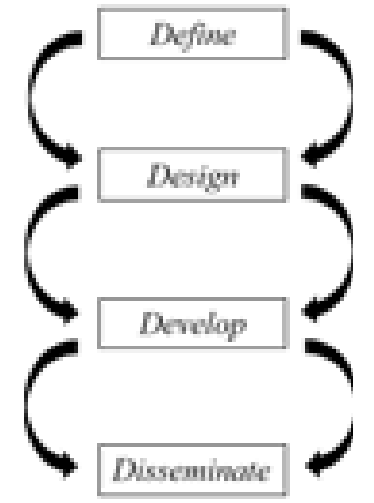

Chart.1 Stages of Research 4D

\section{Data Collection Instruments and Techniques \\ Research Instruments Data}

Collection instruments that will be used include: interview questionnaires for students for needs analysis, validation sheets of teaching materials by material experts, media experts, linguists, readability questionnaires for teaching materials for students, student questionnaire responses to teaching materials, learning execution sheets, questionnaires the effectiveness of teaching materials, field note sheets, and learning motivation tests.

\section{Data Collection Techniques}

Data collection techniques can be described as follows. 1) Interview technique for students of physical and health physical education study programs to obtain preliminary data regarding students' needs for organizational subject and com- 
petition system. 2) Technique of analyzing course documents in the form of syllabus and SAP, as well as identifying weaknesses of organizational teaching materials and the previous version of the competition system. 3) The use of questionnaires to find out data validation of teaching materials, and student responses to organizational teaching materials and competition systems for sports education developed. 4) Written test to measure student motivation. 5) Observation sheet to assess the readability of teaching materials for students, students' responses to teaching materials, sheets of the implementation of learning, the effectiveness of teaching materials and record supporting data during the implementation of learning.

\section{Data Analysis Technique}

1) Qualitative descriptive analysis is used to process qualitative data in the form of suggestions, criticisms, and comments from validators and students. The analysis is done by grouping and describing qualitative information obtained from expert validation sheets and questionnaires for students. 2) Validation sheet data analysis of the organization and descriptive match system are used to process data obtained from validation sheets and student assessment questionnaires. Data will be converted in percentage form with the following formula (Sudijono, 2008)

$$
\begin{aligned}
& \mathrm{P}=\quad \mathrm{F} \quad \mathrm{X} 100 \% \\
& \mathrm{~N} \\
& \text { Information : }
\end{aligned}
$$

F: The frequency that is being sought for the percentage

$\mathrm{N}$ : Number of cases (number of frequencies from the number of individuals)

P: Percentage figures

Table 1. Eligibility Criteria for Textbooks Scale.

\begin{tabular}{cc}
\hline Scale (\%) & Eligibility Criteria \\
\hline $85-100$ & worthy with a very good predicate \\
$65-84$ & worthy with a good predicate \\
$45-64$ & decent with enough predicate \\
$0-44$ & not feasible \\
\hline
\end{tabular}

\section{RESULTS AND DISCUSSION}

\section{Define Phase Results}

The define phase (initial analysis) researchers conducted by interviewing students who had attended organizational courses and the previous competition system. The results obtained are information that the books they have been using are still of a general nature, not attracting interest, so the conclusion obtained is the need to develop textbooks that can increase motivation and understanding of student concepts. In addition, at this stage the researchers compiled a rps that became a reference in preparing the contents of the book. The rps that was made had referred to the curriculum and was based on an analysis of the needs of pjkr students.

\section{Results of design phase}

As thiagarajan said on (Afandi, 2015) argues that the selection of media and format for materials and the production of an initial version of teaching materials was a major aspect of the design phase, the researchers initially chose a4 paper sizes for the draft book. The covers and pages per chapter are designed with adobe photoshop. The results of this stage are producing a draft textbook consisting of a cover (cover page), preface, table of contents, instructions for use, and basic competencies in each chapter.

The contents section consists of several chapters (introductory material, main material, sample questions and exercises). Here is the explanation. The cover is colored red reflecting the enthusiasm of students who take courses at ikip budi utomo malang. The front cover contains the title of the book and the author while the back cover contains a brief description of the organization's textbook and the game system for sports education developed.

In each chapter there is a picture of qr code containing a video about the material to be studied. The contents section consists of the main material, summary, sample questions and exercises. The introduction is intended for apperception, the main material contains material that is associated with the world of sports. Examples of questions and practice questions are also always related to recovery material.

\section{Develop Phase Results}

This textbook was validated by 3 experts, namely material experts, media experts (teaching materials experts), and linguists. Material validator by Drs. Sulikan, MS (PJKR Lecturer). Language validator by Dr. Endang, M.Pd (Indonesian Language Lecturer). Media validator by Ms. Agusti Mahardika, M.Pd. The results of the evaluation of each validator are calculated and made in the form of a percentage.

\begin{tabular}{|c|c|c|}
\hline \multirow{2}{*}{$\begin{array}{l}\text { Validator } \\
\text { Code }\end{array}$} & \multicolumn{2}{|c|}{ Validation Student Activity } \\
\hline & $\%$ & Criteria \\
\hline V1 & $83 \%$ & $\begin{array}{l}\text { worthy with a very good } \\
\text { predicate }\end{array}$ \\
\hline
\end{tabular}

Table 2. Results of Expert Validation of Materials 
Tabel 3. Results of Validator Linguists

\begin{tabular}{|c|c|c|}
\hline \multirow{2}{*}{$\begin{array}{l}\text { Validator } \\
\text { Code }\end{array}$} & \multicolumn{2}{|c|}{ Validation Student Activity } \\
\hline & $\%$ & Criteria \\
\hline V2 & $83 \%$ & $\begin{array}{l}\text { worthy with a very good } \\
\text { predicate }\end{array}$ \\
\hline
\end{tabular}

Tabel 4. Results of Media Expert

\begin{tabular}{|c|c|c|}
\hline \multirow{2}{*}{$\begin{array}{l}\text { Validator } \\
\text { Code }\end{array}$} & \multicolumn{2}{|c|}{ Validation Student Activity } \\
\hline & $\%$ & Criteria \\
\hline V1 & $79 \%$ & $\begin{array}{c}\text { worthy with a good } \\
\text { predicate }\end{array}$ \\
\hline
\end{tabular}

The average results of the validation of the three validators are in good and proper criteria. In addition to evaluating in the form of numbers, the validator provides several suggestions as a reference for the revision of the textbook, among others.

Based on individual and small group tests, it is known that there are some things that need to be revised, especially related to the way of writing, paper size and writing limits. This has been followed up and has been revised. The original paper A4 was changed to A5.

Based on the implementation of textbooks in learning, it is known that learning goes well. Based on the motivation questionnaire, it is known that student motivation has increased from before. Based on the final test results, it is known that the student completeness reaches $80 \%$.

\section{Results of the Desiminate Phase}

The result of the desiminate stage is the distribution of textbooks to be used in organization lectures and competition systems especially for sports majors.

\section{CONCLUSION}

Based on the data that has been collected at each stage of research that has been passed, it can be concluded that the product of teaching materials based on QR Code system and competition organization courses can and are feasible to use.

\section{REFERENCES}

Afandi, R. (2015). Pengembangan Media Pembelajaran Permainan Ular Tangga Untuk Meningkatkan Motivasi Belajar Siswa Dan Hasil Belajar Ips Di Sekolah Dasar. Jinop (Jurnal Inovasi Pembelajaran), 1(1), 77-89.

Ani Asiani, Harini, J. A. N. (2017). Penerapan Model Attention, Relevance, Confidence, And Satisfaction (Arcs) Untuk Meningkatkan Motivasi Dan Hasil Belajar Siswa Kelas X Pemasaran 1 Smk Negeri 1 Surakarta Tahun Pelajaran 2016/2017. Pendidikan Ekonomi, Fkip Universitas Sebelas Maret, 3(1), 1-11.

Guo, D., Cao, J., Wang, X., Fu, Q., \& Li, Q. (2016). Combating Qr-Code-Based Compromised Accounts In Mobile Social Networks. Sensors (Switzerland), 16(9), 1-17. Https://Doi. Org/10.3390/S16091522

Meydanoglu, E. S. B. (2013). Qr Code: An Interactive Mobile Advertising Tool. International Journal Of Business And Social Research, 3(9), 26-32. Https://Doi.Org/10.18533/Ijbsr.V3i9.289

Monicca, I., Subkhan, \& Setiyani, R. (2015). Pengaruh Minat Belajar, Motivasi Belajar Dan Prestasi Belajar Matematika Terhadap Prestasi Belajar Akuntansi Siswa Kelas X Jurusan Akuntansi Di Smk Palebon Semarang. Economic Education Analysis Journal, 4(2), 414-426.

Poerwanti Hadi Pratiwi, Nur Hidayah, Dan A. M. (2017). Pengembangan Modul Mata Kuliah Penilaian Pembelajaran Sosiologi Berorientasi Hots. Cakrawala Pendidikan, Xxxvi(2), 201209.

Saluky. (2016). Pengembangan Bahan Ajar Matematika Berbasis Web Dengan Menggunakan Wordpress. Eduma, 5(1), 80-90.

Sudijono, A. (2008). Pengantar Statistik Pendidikan. Jakarta: Grafindo Persada.

Sukmadinata, N. . (2005). Metode Penelitian Pendidikan. Bandung: Remaja Rosdakarya.

Sulkipani, E. E. F. Dan. (2016). Pengembangan Bahan Ajar Berbasis Muatan Lokal Pada Mata Kuliah Pendidikan Kewarganegaraan. Jurnal Civics, 13(2), 113-126.

Suryadinata, N. F. Dan N. (2016). Pengembangan Bahan Ajar Mata Kuliah Aljabar Linear Berbasis Open Ended. Aksioma Jurnal Pendidikan Matematika, 5(2), 145-151.

Vahlia, R. A. Dan I. (2016). Pengembangan Bahan Ajar Berbasis Masalah Pada Mata Kuliah Matematika Ekonomi Program Studi Pendidikan Matematika. Aksioma Jurnal Pendidikan Matematika, 5(2), 152-160.

Winarno, M. E. (2011). Metodologi Penelitian Dalam Pendidikan Jasmani. Malang: Media Cakrawala Utama Press. 